\title{
IMAGE RETRIEVAL SYSTEM OF LANDSCAPE IMAGE USING KANSEI WORDS AS THE REFERENCE KEY
}

\author{
Yuukou HORITA, Naoki MUROOKA, Kazuhiro HONDA and Tadakuni MURAI
}

Graduate School of Science and Engineering, University of Toyama, 3190 Gofuku, Toyama 930-8555, Japan

\begin{abstract}
In our previous work, to extract the KANSEI information received from a landscape image, we investigated the evaluation experiment by the Semantic Differential method. By analysing the obtained data using the factor analysis, we found out 4 factors associated with KANSEI information. In this paper, we consider the KANSEI modeling which is connecting with a landscape image and the KANSEI factors. By using MPEG-7 descriptors such as Scalable Color Descriptor and Edge Histgram Descriptor, the Saliency Map information of Visual Attention, and the KANSEI factors of monochromatic color, we can estimate the KANSEI information using the potential interpolation method. In addition, as an example of image database system applying this $K A N S E I$ modeling method, we consider the image retrieval system which used the KANSEI information as the reference key.

Keywords : KANSEI information, MPEG-7, Saliency Map, Semantic Differential method, Image database
\end{abstract}

\section{1.はじめに}

個人の自己表現やコミュニケーションの能力を高める手段 としてマルチメディアは重要視されており,特に, 画像メディ アはその情報量の多さゆえに，より高度なコミュニケーショ ンやデータベース利用の中心的存在に位置付けられている. 近年では，デジカメやカメラ付き携帯電話の普及により，旅 行先などで多くのシーンを撮影する場合が多くなってきた。 我々はこの撮影した画像を PC などに蓄積保存する場合が多 く, PC 内には数多くの景観画像が蓄積されていることも珍 しくない．この枚数が膨大になるにつれて，蓄積された景観 画像の中から, 自分がイメージする景観画像を効率良く検索 したいという要求が高まってきており，これを実現するため には感性語を検索キーとした景観画像の画像検索システムの 開発が必要となってくる.

一般的に感性モデリング技術とは，メディアから何らかの 情報を抽出し，人間の感性的な反応を予測する技術である が, 我々は画像メディアという入力情報と感性情報という出 力情報との関係を事例から学習する方法により，感性情報を 予測する感性モデリング技術が開発できると考えている。こ の感性モデリング技術を利用することにより, 感性語を検索 キーとした景観画像の画像検索システムが開発できると考え ている.

我々の先行研究では，対象となる景観画像を実際に観察し た時に受け取る感性情報を抽出するために SD（Semantic Differential）法による評価実験を行い, このデータを因子 分析することにより, 景観画像から受け取る感性情報に関連 した因子が 4 種類存在することを示した。この実験により，
入力情報である景観画像と出力情報となる 4 因子の感性情 報が与えられたことになる。

そこで，本論文では，この景観画像を入力情報とし，評価 実験で得られた感性因子を出力情報とする感性モデリングを 検討した，具体的には，景観画像から受け取る感性情報を推 定するために，MPEG-7で規定されたビジュアル記述子の 色彩とエッジの各特徵量 $[10,11]$, Visual Attention を表す Saliency Map 情報 [12]，単色刺激における色彩感性情報 [13］等を用いて，景観画像から受け取る感性情報を推定す ることを試みた。ささらに, この感性モデリング技術を利用し た画像データベース検索の応用例として，推定した感性情報 をデータのインデキシングに利用し，SD 法によって抽出さ れた感性情報を入力キーとして画像を検索する画像検索シス テムの構築を試みた.

これまでに多くの画像検索技術が提案されており，その多 くは検索キーを用いるもの，類似画像で検索するもの，感性 語で検索するものなどが上げられる。感性語を用いる画像検 索は，画像に付加されているテキスト情報の類似性や画像本 来が持つ構造や特徵の類似性を議論するのでなはく，ユーザ が必要としている印象や感性を元来有している候補画像を検 索することに相当するので，我々人間にとって一番高次元な 検索手法であるといえる.

感性検索とそれに関連する技術の代表的なものとして，こ れまでに, 栗田ら [1] の画像の色彩分布と印象語の多変量 解析による対応づけ，八村ら［2］の主要色と背景色に分離 した画像の配色と配色データベースとの適合度による画像と 印象との対応づけ，田中［3］らの誘目性に着目した注目領 域の抽出，木本 [4]による感性語の配色パターンと色彩情 報との関係を利用した感性画像データベースの試作と評価, 
近藤ら［5］による画像の印象を表す配色であるイメージカ ラーを用いた感性画像データベースの試作と評価などがあげ られ，これらは色彩情報を積極的に利用している。

さらに，従来とは異なるアプローチとして，椋木［6］ら の対義関係にあるいくつかの代表的な感性語対の組み合わせ で他の感性語を表現し画像検索する手法があるが, 複数の感 性語による入力がまだ検討されてない事が課題であった。 ま た, 池添ら [7] のニューラルネットワークを用いて感性語 対の程度と音楽感性との関係を検索に利用する手法がある が，画像情報への適用可能性は議論されていない，

これまでの感性語による画像検索では,「綺麗な画像」や 「がっしりした画像」というような形容詞である感性語のみ を離散的に取り扱っていた。一方,「非常に綺麗な画像」や「や やがっしりした画像」というように, “接頭語＋形容詞”と いうような感性語を連続量として扱う試みは, ユーザの画像 検索要求を率直に表現するうえで重要であるにもかかわら ず, これまであまり詳細な議論がなされていない. そこで, 本論文では, 画像から推定する感性情報を連続量として議論 することが従来研究との大きな相違である.

\section{SD法による評価}

実験先行研究で得られた景観画像に対する感性情報を得た 評価実験について簡単に述べる，景観画像における感性情報 を推定するためには，まず人間が景観画像から受け取る感性 情報を形成する因子を明らかにし，その特性を調べ解析する 必要がある，そこで，SD 法に基づいた主観評価実験を行い， 景観画像の感性情報を構成する感性因子がどのようなもので あるかを調べた [8]. 実験は表 1 の条件で行った，実験で 用いた景観画像 [9]は，昼景と夜景におおまかに分類でき， 画像コンテンツは 5 種類程度 (近代的建築物, 歴史的建築物, 山, 海, 平地) の対象物に分類できた. 昼景と夜景, 対象物 の組み合わせを考えて計 36 枚を選定したＳD法による実 験結果を因子分析することにより 4 つの有意な因子が抽出

表 1 SD 法による評価実験の条件

\begin{tabular}{c|l}
\hline \hline 評価画像 & 景観画像 $(640 \times 480$ pixel, 24bpp $) 36$ 枚 \\
\hline 評価尺度 & 30 尺度 $($ 形容詞 $), 7$ 段階評価 \\
\hline 評定者数 & 53 名 (大学生 $)$ \\
\hline 提示方法 & ランダム提示 $(1$ 回ずつ), 提示時間は無制限 \\
\hline
\end{tabular}

表 2 各因子と関係の深い評価語対

\begin{tabular}{|c|c|}
\hline 因子 & 評価語対 \\
\hline 因子 1（評価性） & $\begin{array}{c}\text { 好き一嫌い, きれい一きたない } \\
\text { 陽気な一陰気な }\end{array}$ \\
\hline 因子 2（活動性） & $\begin{array}{c}\text { 派手な一地味な, 静的な一動的な } \\
\text { 複雑な一単純な }\end{array}$ \\
\hline 因子 3（力量感） & $\begin{array}{c}\text { かたい一やわらかい, 強い一弱い } \\
\text { 暖かい一冷たい }\end{array}$ \\
\hline 因子 4（明彩感） & $\begin{array}{l}\text { 濃い一薄い, 明るい一暗い } \\
\text { 味わい深い一味気ない }\end{array}$ \\
\hline
\end{tabular}

された。抽出された因子と関係が深い評価語対から, 第 1 因 子を「評価性」の因子，第 2 因子を「活動性」の因子，第 3 因子を「力量感」の因子, 第 4 因子を「明彩感」の因子と 定めた，表 2 に，各因子と関係の深い評価語対例を示す.

なお，SD 法の評価実験分では教師用データが不足してい ると思われたため，抽出された 4 因子を評価尺度に利用し て追加実験を行い, 景観画像 200 枚分の感性情報を得た。 表 3 に実験条件を示す。

200 枚の各画像に対して評定者全員の平均評価得点を求 め, これから評定者に関する各因子の標準偏差を求め, これ を基にして評価值の平均值に対する $95 \%$ 信頼区間を求め た。な扮評価值のダイナミックレンジは $-3 \sim 3$ である. と もに未知の平均 $\mu$ と分散 $\sigma^{2}$ をつ正規分布から抽出した大 きさ $\mathrm{n}$ の標本の平均と分散を各々 $x, s^{2}$ とすれば，平均 $\mu$ に 対する $100(1-\alpha) \%$ の信頼区間は以下の形で表される.

$$
x \pm t_{n-1 ; \frac{\alpha}{2}} \frac{\mathrm{s}}{\sqrt{n-1}}
$$

表 4 はその結果である. 4 因子ともに \pm 0.6 程度の信頼区 間となった。よって, 評価実験で得られた画像に対する評価 得点には \pm 0.6 程度の誤差があるので, 因子得点の推定精度 としては, 平均推定誤差として \pm 0.6 程度を目標とする.

\section{MPEG-7VisualPart}

MPEG-7 はディジタル映像を含むマルチメディアコンテン ツを記述するためのメタデータの国際標準規格である [10].

\subsection{Scalable Color Descriptor}

Scalable Color Descriptor（SCD）は, HSV 色空間の色ヒ ストグラムに Haar 変換（図 1 (a) 参照) ベースのエンコー ドを施した記述子である [10]. H(Hue) は色相, S (Saturation) は彩度, V (Value) は明度を表す。画像を HSV 色空間に変 換した後， Hを 16 レベル， $\mathrm{S}$ を 4 レベル，Vを4レベルに それぞれ分割し，256-binのカラーヒストグラムを作る（図 1 (b) 参照). ここで, $\mathrm{H}$ は $0 \sim 2 \pi, \mathrm{S}$ は $0 \sim 1, \mathrm{~V}$ は $0 \sim 1$ である，さらに，Haar変換によって，256-binのカラーヒ

表 3 追加実験の条件

\begin{tabular}{c|l}
\hline \hline 刺激材料 & 景観画像 $(640 \times 480$ pixel, 24bpp) 200 枚 \\
\hline 尺度 & 4 尺度（抽出された感性因子), 7 段階評価 \\
\hline 評定者数 & 15 名 (大学生) \\
\hline 提示方法 & ランダム提示 $(3$ 回ずつ), 提示時間は無制限 \\
\hline
\end{tabular}

表 4 平均値の信頼区間

\begin{tabular}{c|c|c}
\hline \hline 因子 & 標準偏差 & 信頼区間 \\
\hline 因子1 (評価性) & 1.16 & \pm 0.64 \\
\hline 因子 2 (活動性) & 1.23 & \pm 0.67 \\
\hline 因子 3 (力量感) & 1.11 & \pm 0.61 \\
\hline 因子 4 (明彩感) & 1.19 & \pm 0.65 \\
\hline
\end{tabular}




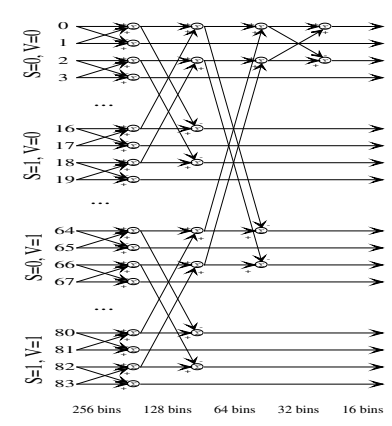

(a) Haar Transform

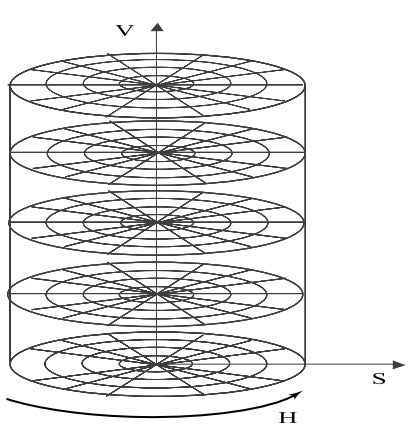

(b) 256-bin

図 1 Scalable Color Descriptor の概要

表 5 HSV 色空間等価分割テーブル [10]

\begin{tabular}{c|c|c|c}
\hline \hline coefficients & $\mathrm{H}$ & $\mathrm{S}$ & $\mathrm{V}$ \\
\hline 16 & 4 & 2 & 2 \\
\hline 32 & 8 & 2 & 2 \\
\hline 64 & 8 & 2 & 4 \\
\hline 128 & 8 & 4 & 4 \\
\hline 256 & 16 & 4 & 4 \\
\hline
\end{tabular}

ストグラムをそれぞれ $128 ， 64 ， 32 ， 16$ の Haar 係数（ヒ ストグラム）を求めることができる，表 5 に H， S，V民れ ぞれの分割レベルを示す。

\subsection{Edge Histogram Descriptor}

Edge Histogram Descriptor(EHD) は, ローカルエッジ情 報をヒストグラム化したもので, 画像を $4 \times 4$ の 16 区画に 分割し, 区画ごとに図 2 (a)に示す 5 タイプのエッジ (vertical, horizontal, 45degree, 135degree, non-directional) がどの 程度存在するかを記述する。1 16 個に分割されたそれぞれの 領域を、サブイメージと呼ぶ，それぞれのサブイメージに対 して，エッジタイプが 5 つあるので，全体で $16 \times 5=80$ の
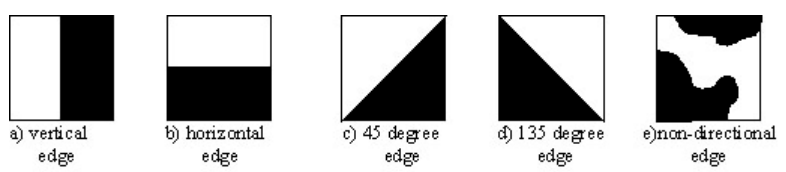

(a) Five types of edges
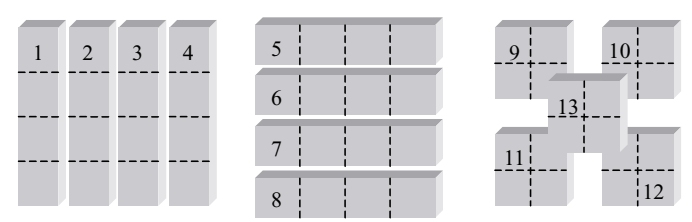

(b) Semi-Global-bin
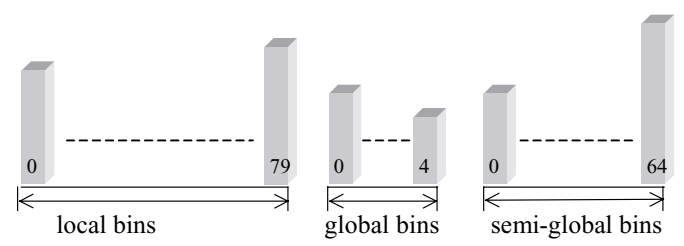

(c) Overall histogram semantics

図 2 Edge Histogram Descriptor の概要

ヒストグラム的なローカルビン（local bins）を持つ.

ローカルエッジヒストグラムビンだけでは, 効率的なマッ チングが行えないため, ローカルエッジ分布と同様に, 画像 全体のエッジ分布といくつかの水平方向と垂直方向のセミグ ローバルエッジ分布に対するエッジ分布情報が必要となる.グ ローバルエッジは画像全体に対するエッジ分布を表してお り, 元来 5 つのエッジタイプがあるので, グローバルエッジ ヒストグラムは 5 つのビン（bin）を持つ. ビン（bin）の值 はそれぞれの領域のローカルエッジのタイプごとにビン （bin）の值を累積し，正規化することによって得られる。

同様に，セミグローバルエッジは，図 2 (b) で示される いくつかのサブセットからビン（bin）值を得ることができ る.13の異なるクラスターがあり，それぞれのクラスター に対して $5 つ の$ 異なったエッジタイプのためのエッジ分布 を生成することで得られる。

結果として, 全体で 80bins (local) +5 bins (global) +65 bins $(13 \times 5$, semi-global $)=150$ のヒストグラムを得る (図 $2(\mathrm{c})$ 参照 $).$

\section{Saliency Map}

人間は画像を観察した場合, 特定の領域の物理的刺激(色, 形テテクスチャなど）に注意を引きつけられることが知られ ている。 この注視領域を表現するモデルとして SaliencyBased Search Mechanismに基づくSaliency Mapがある [12]. Saliency Map は, 物体の目立つ部分を 2 次元マップ で表したものであり, 図3にそのモデルを示す.

まず，入力画像を線形フィル夕によって intensity, color, orientationの特徵に分け，Low-pass フィルタとサブサンプ

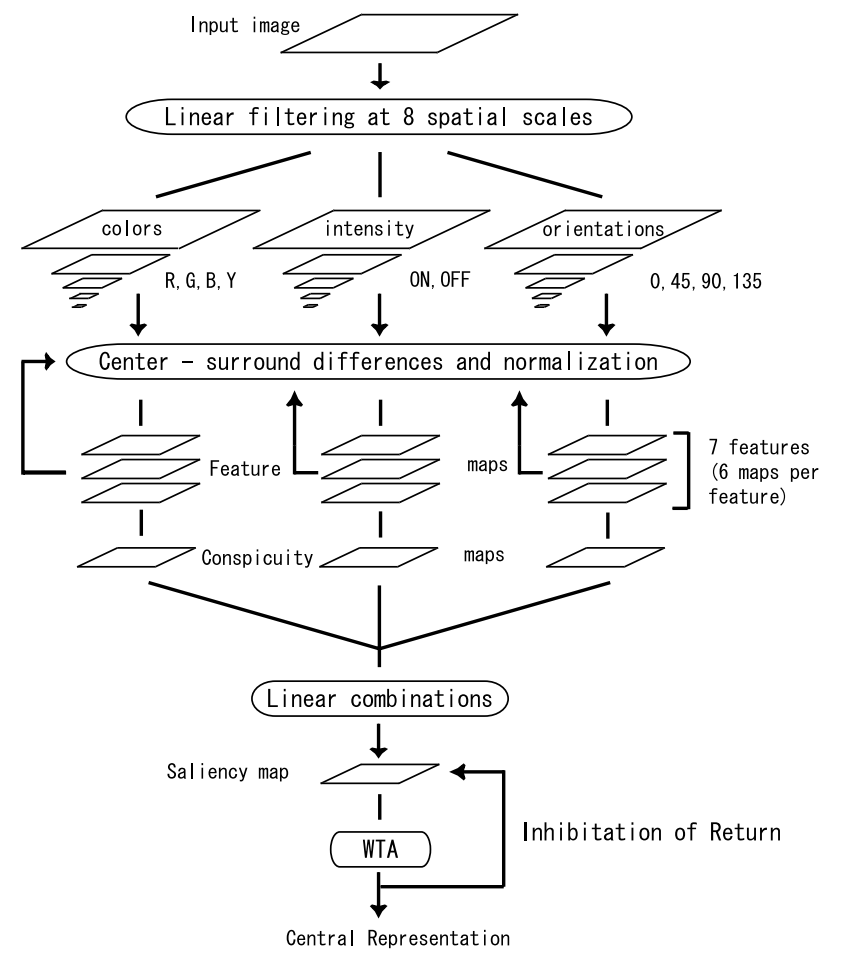

図 3 Saliency-Based Search Mechanism のモデル[12] 


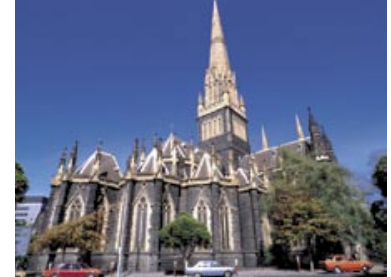

(a) Original image

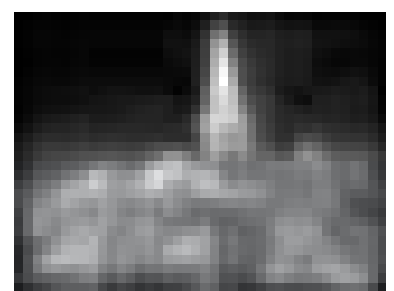

(b) Saliency Map
図 4 Saliency Map の例

リングから成る Gaussian pyramid 法を用いて 9つのスケー ルの画像を作る。 その後, それぞれの特徴において視覚許容 範囲と近似された視野の中心 $c \in\{2,3,4\}$ と周辺視 $s=c+\delta$, $\delta \in\{3,4\}$ との差を計算し，6つの特徴マップを作る。 それ ぞれの特徵マップごとに正規化し，これらを線形結合するこ とによって, 一つの“Saliency Map”が得られる. 図 4 は Saliency Mapの一例であり, 輝度の高い部分が注視されや すいことを示している.

\section{5. 単色における色彩感性情報}

人間は単色に対しても色彩感性を受け取ることから, 多く の色彩で構成される景観画像の感性情報の予測に, 単色の色 彩感性も利用できると考えた。 そこで, 図 5 のように画像 を 9 つの領域に分割し, 各領域の HSV 色空間上での最大頻 度ヒストグラムの色情報をもとに, 単色の色刺激から受け取 る感性情報を推定し, 色彩感性值（第 1 因子：評価性，第 2 因子:力量性, 第 3 因子: 活動性) として利用する. 文献 [13] で得られている 201 色の因子得点を基にして, ポテンシャ ル補間による色彩感性值の推定を行った。ポテンシャル補間 法は, 与えられたデー夕点から補間したい点までの距離に比 例してデー夕点の值に重みをかけ, その総和を補間したい点 での補間值とする方法である。色彩感性值は式（1)～(3) のように定義した. $f^{\prime}{ }_{1{ }^{\prime} l_{i}}, f^{\prime}{ }_{2 c o l_{i}}, f^{\prime}{ }_{3 c o l} l_{i}$ は, 各小領域 $i$ ごとの 評価性, 力量性, 活動性の色彩感性值である.

$$
f_{1 c o l_{x}}=\frac{1}{9} \sum_{i=0}^{8} f_{1 c o l_{i}}^{\prime}
$$

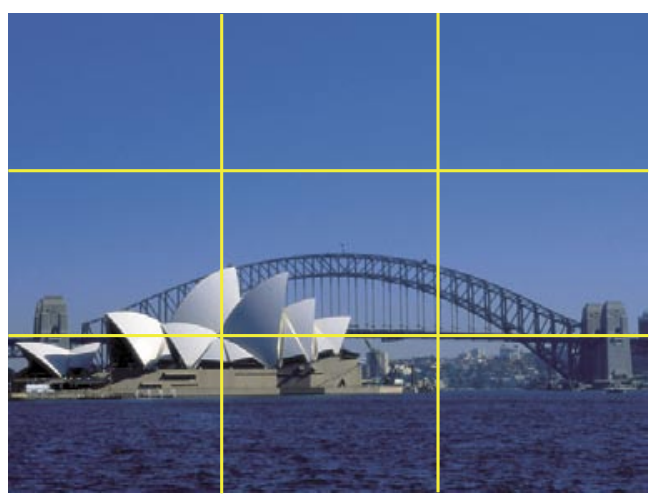

図 5 画像の分割例

$$
\begin{aligned}
& f_{2 c o l_{x}}=\frac{1}{9} \sum_{i=0}^{8} f^{\prime}{ }_{2 c o l_{i}} \\
& f_{3 c o l_{x}}=\frac{1}{9} \sum_{i=0}^{8} f^{\prime}{ }_{3 c o l_{i}}
\end{aligned}
$$

\section{6. 感性情報の推定方法}

景観画像の感性情報を予測するために, 以下の手順で推定 を行った。

- 入力画像より前述した画像特徵量を抽出し, 教師用画像 データ群との類似度を求める

・類似度の高かった $\mathrm{n}$ 個の教師用画像データの感性情報 を, 類似度によって重みづけをし, ポテンシャル補間に よって入力画像の感性情報を推定する.

\section{1 類 似度計算}

類似度 $S_{x}$ は式 (4), 式（5）によって算出した。

$$
S_{x}=\frac{1}{D_{x}}(x=1,2, \ldots, 199)
$$

$$
\begin{aligned}
D_{x} & =\omega_{1} \Delta S C D_{x}+\omega_{2} \Delta E H D_{x}+\omega_{3} \Delta S M_{x} \\
& +\omega_{4} \Delta f_{1 c o l_{x}}+\omega_{5} \Delta f_{2 c o l_{x}}+\omega_{6} \Delta f_{3 c o l_{x}}
\end{aligned}
$$

ここで， $D_{x}$ は計算に用いた $x$ 番目の教師用画像データと入 力画像との距離尺度を表している。 また, $\triangle S C D_{x}, \triangle E H D_{x}$, は入力画像と教師用画像データとの画像特徵量の距離尺度 で, MPEG-7 で規定されている [10]. $\Delta S M_{x}$, は入力画像と 教師用画像データとの Saliency Map の距離尺度, $\Delta f_{1 \text { col }_{x}}, \Delta f_{2 \text { col }_{x}}, \Delta f_{3 c o l_{x}}$ は入力画像と教師用画像デー夕との単 色の色彩感性值の距離尺度を表している。 $\triangle S C D_{x}$ は, 256 から 16 までの 5 種類のカラーヒストグラムがあるので 5 個の距離尺度がある。これらの距離尺度は次元が異なるの で $\omega_{1} \sim \omega_{6}$ の重み係数を乗じて距離尺度 $D_{x}$ を求める。 こ こで用いた各距離尺度を式（6）（11）に示す. なお，教 師用画像デー夕は下付き添字“x”で，入力画像は下付き添 字“in”で区別する。

$$
\begin{aligned}
& \Delta S C D_{x}=\sum_{i=0}^{k}\left|S C D_{x}[i]-S C D_{\text {in }}[i]\right| \\
& (k=256,128,64,32,16) \\
& \Delta E H D_{x}=\sum_{i=0}^{79}\left|L E_{x}[i]-L E_{\text {in }}[i]\right| \\
& +5 \times \sum_{i=0}^{4}\left|G E_{x}[i]-G E_{i n}[i]\right| \\
& +\sum_{i=0}^{64}\left|S G E_{x}[i]-S G E_{i n}[i]\right| \\
& \Delta S M_{x}=\sum_{i=0}^{1199} S M_{x}[i]-S M_{i n}[i] \mid \\
& \Delta f_{1 \text { col }_{x}}=\left|f_{1 \text { col }_{x}}-f_{1 \text { col }_{\text {in }}}\right|
\end{aligned}
$$




$$
\begin{aligned}
& \Delta f_{2 c o l_{x}}=\left|f_{2 c l_{x}}-f_{2 c o l_{i n}}\right| \\
& \Delta f_{3 c o l_{x}}=\left|f_{3 c l_{x}}-f_{3 c l_{\text {in }}}\right|
\end{aligned}
$$

\section{2 ポテンシャル補間による推定}

類似度 $S_{x}$ が大きいものから順に $\mathrm{n}$ 個のデー夕を使用してポ テンシャル補間により感性情報を算出する，な掠，補間する 際に式（12）のように類似度による重みづけを加えた，最終 的に推定される感性情報を式（13）のように定義する， $w_{x}$ は 重み係数, $F_{j}$ は推定された感性因子得点, $F_{j x}$ は教師用画像デー 夕 $x$ の感性因子得点を表す。

$$
\begin{aligned}
& w_{x}=\frac{s_{x}}{\sum_{k=1}^{n} S_{k}} \\
& F_{j}=\sum_{x=1}^{n} w_{x} \cdot F_{j x} \quad(j=1,2,3,4)
\end{aligned}
$$

\section{3 重み係数の最適化}

式（5）で用いた重み係数 $\omega_{1} \sim \omega_{6}$ を求めるために，感性 推定結果の平均誤差が小さくなるように遺伝的アルゴリズム （GA）を用い，重みパラメータの值を計算した，GAのパラ メー夕を表 6 に示す。本論文で提案している推定法は，ポ テンシャル補間の補間数と SCD の bin 数に自由度があるの で，事前に 5 種類の全 SCD に対して，最適なポテンシャル 補間の補間数を求めた。その結果, 最良な組及合わせは，ポ テンシャル補間の補間数が 11，SCD は 32-binであった。 以降この結果で議論を進める。この時の求められた重み係数 を表 7 に示す.

\section{7. 実 験 結 果}

評価実験で用いた 200 枚の画像デー夕を教師用画像デー タとして, 前述の推定方法により感性情報の推定を行った。

表6 GAパラメータ

\begin{tabular}{c|c}
\hline \hline 個体数 & 100 \\
\hline 染色体 & 6 \\
\hline 世代 & 300 \\
\hline 交叉 & 単純交叉 \\
\hline 選択 & $\begin{array}{c}\text { エリート保存方式 } \\
\text { ランク方式 }\end{array}$ \\
\hline 変異率 & 0.1 \\
\hline 適応度 & 推定結果の平均誤差 \\
\hline
\end{tabular}

表 7 GA により求められた重み係数

\begin{tabular}{c|c|c|c|c|c|c}
\hline \hline 因子 & SCD & EHD & SM & $f_{\text {1col }}$ & $f_{\text {2col }}$ & $f_{3 c o l}$ \\
\hline 1 & 0.93 & 0.07 & 0.40 & 0.65 & 0.28 & 0.49 \\
\hline 2 & 0.94 & 0.03 & 0.13 & 0.05 & 0.01 & 0.11 \\
\hline 3 & 0.42 & 0.96 & 0.49 & 0.05 & 0.11 & 0.01 \\
\hline 4 & 0.66 & 0.02 & 0.64 & 0.76 & 0.01 & 0.75 \\
\hline
\end{tabular}

表 8 補間による推定値と実測値との誤差

\begin{tabular}{c|c|c|c|c}
\hline \hline 因子 & 平均 & 最大 & 平均 $(r)$ & 最大 $(r)$ \\
\hline 因子 1 (評㖶性) & 0.39 & 1.57 & 0.41 & 1.52 \\
\hline 因子2 (活動性) & 0.73 & 2.23 & 0.69 & 2.83 \\
\hline 因子 3 (力量感) & 0.53 & 1.92 & 0.60 & 2.15 \\
\hline 因子4 (明彩感) & 0.50 & 2.01 & 0.51 & 2.35 \\
\hline
\end{tabular}

\section{1 感性情報の推定結果}

推定された感性因子得点と実験によって得られた感性因子 得点との推定精度を表 8 に示す。性能比較のために, $\mathrm{SCD} 32$ ビンの值でステップワイズ回帰分析により各感性因 子を推定した結果（r と記述）も合わせて示す。なお， $\mathrm{SCD}$ は色彩情報のヒストグラムを表しているので，画像特徴量と しては代表的なものであると考えられる。この結果と比較す ることにより，感性モデリング技術に用いた要素の有効性が 議論できる.

平均誤差については，因子 2（活動性）が目標としていた 信頼区間からやや外れてしまった。また，最大誤差について も，目標としていた信頼区間を大きく外れている，推定値と 実測值との関係では，全体的に分布の傾きが小さく，感性值 がさの大きいところで外れている，特に，因子 2 にばらつ きが見られる。

過去の類似した研究成果から容易に推測できることである が，色彩情報は感性情報を予測するには非常に強力な情報で あるといえる，実際，画像特徴量のうち SCD32 ビンの結果 を用いて感性情報とのステップワイズ回帰分析を行った結果 は，最大誤差が大きいものの，平均誤差は小さく，色彩情報 のヒストグラムを意味する SCD 32 ビンだけでステップワイ ズ回帰しても，ある程度の感性情報が予測できる。しかしな がら，本論文で提案する手法を用いた推定では，4つの感性 因子のうちほとんどの因子の平均誤差が改善されている。さ らに, 最大誤差についても, 本論文の手法では改善される傾 向が見られる，特に，平均誤差の大きい因子 2 では改善効 果が大きいことがわかる，よって，本論分で採用した感性モ デリング技術は，因子に対する程度の差はあるものの，平均 誤差や最大誤差を小さくするには有効な手段であるといえ る。また，平均誤差は 95\% 信頼区間をほぼクリアしている ので，最大誤差を極力小さくできるような推定法を確立する ことが重要であると考える.

本推定法は感性情報が既知の教師画像群から未知の画像に おける感性情報をポテンシャル補間により推定する手法なの で，距離尺度空間において未知画像の空間内の位置が既存 データとの内挿関倸にあれば，その感性值はある程度精度良 く推定できるが，外挿関係になってしまうとポテンシャル補 間はあまり有用ではない，よって，感性值が極端に大きな教 師画像デー夕が多く存在すれば，推定精度の向上につながる 可能性もある。

特徴量に対する重み係数では，その值が大きければ推定す るにあたり重要な特徴量といえる。 
- 因子 1 (評価性)

$\mathrm{SCD}$ と $f_{1 \mathrm{col}}$ (単色の色彩感性值: 評価性) が因子 1 (評価性) の推定に強く影響している. 特に, SCDの重み係数が大 きいことより，画像中の色彩情報の影響が強い.また， $f_{1 c o l}$ の係数が大きいことから, 単色の “評価性” と画像の “評価性”とは類似した関係がある.

- 因子 2(活動性)

$\mathrm{SCD}$ が因子 2 (活動性)の推定に特に重要である. $f_{3 c o l}$ (単 色の色彩感性值: 活動性) の係数が小さいので, 単色の “活動性”之画像の“活動性”とは関連性が低い.

- 因子 3 (力量感)

EHDが因子 3 (力量感)の推定に重要であることより, テ クスチャ情報が因子 3 の推定に有用である。他の因子で 有用であったSCDは，この因子に限ってはあまり有用 とはいえない. また, $f_{2 c o l}$ (単色の色彩感性值: 力量性) よ り, 単色の “力量感” と画像の “力量性” との関連性は低い.

- 因子 4 (明彩感)

SCD, Saliency Mapや単色の色彩感性值が因子 4(明彩感) の推定に重要である. EHDが低いことから, 色彩を中心 とした特徴量が因子 4 (明彩感)の推定に有用である。

これらの結果を表 9 にまとめて示す.

\section{2 信頼区間を考慮した検討}

推定された感性情報がどれくらいの精度であるかをチェッ クするために，各因子ごとに $95 \%$ 信頼区間に入る割合を求 めてみた，結果を表 10 に示す。元来, SD 法による主観評 価実験の結果より，感性值はかなりのばらつきを有している ので, 結果的に 60〜80\%の推定データが信頼区間内に収まっ ていることになる.

次に, 信頼区間から外れた画像の傾向について調査した結 果, 次のような特徵が見られた。各 4 因子における実際の 画像例を図 6 に示す。

- 評価性：街並など, 全体的に細かい画像.

- 活動性：全体的に建築物が占める割合が多い画像.

- 力量感: 海や山など, 同系色で構成された画像や全体的 に色相数が少ない画像.

- 明彩感:夕景や夜景など, 全体的に明度と彩度が低い画像.

\section{表 9 各因子の感性推定に有用な特徵量}

\begin{tabular}{c|c}
\hline \hline 因子 & 有用な特徵量 \\
\hline 因子1(評価性) & SCD, $f_{1 c o l}$ \\
\hline 因子2(活動性) & SCD \\
\hline 因子3(力量感) & EHD \\
\hline 因子4(明彩感) & SCD, SM, $f_{1 c o l}, f_{3 c o l}$ \\
\hline
\end{tabular}

表 10 信頼区間に入る割合

\begin{tabular}{c|c|c|c}
\hline $\begin{array}{c}\text { 因子 1 } \\
\text { (評価性) }\end{array}$ & $\begin{array}{c}\text { 因子 } 2 \\
\text { (活動性) }\end{array}$ & $\begin{array}{c}\text { 因子 } 3 \\
\text { (力量感) }\end{array}$ & $\begin{array}{c}\text { 因子 } 4 \\
\text { (明彩感) }\end{array}$ \\
\hline 0.82 & 0.57 & 0.67 & 0.72 \\
\hline
\end{tabular}

(a) factor 1 (Evaluation)

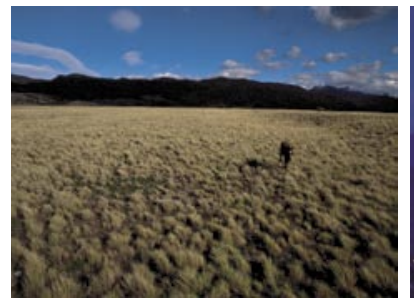

(c) factor 3 (Potency)

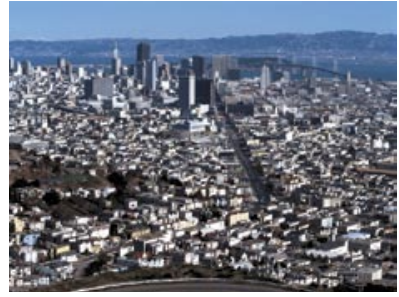

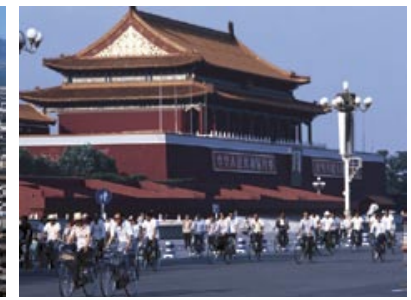

(b) factor 2 (Activity)

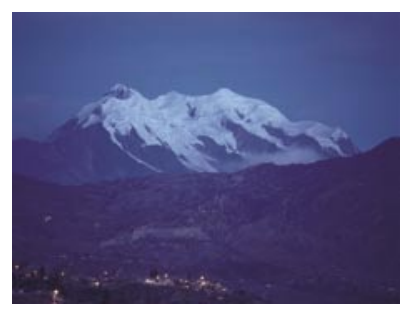

(d) factor 4 (Tone)
図 6 信頼区間から外れた画像例

因子別に推定值を調べてみると, 因子 2（活動性）だけが “-”の方向に多く分布していた。因子 2 (活動性) が信頼区 間から外れたのは, 実測值と推定值の絶対值は同じくらいで あるが，“士”の符号が異なる場合が多かったと考えられる。

\section{8. 画像検索システム}

本論文で提案した感性モデリング技術を利用して, SD 法 によって抽出された景観画像に対する感性情報の 4 因子を 入力キーとした画像検索システムを試作した.

\section{1 システムの仕様}

ユーザは自分がイメージする画像の感性や印象を 4 尺度 の 7 段階值で入力する. 検索結果は入力值とポテンシャル 補間により推定した全教師画像データの感性因子得点のユー クリッド距離を求め, 距離が短い上位 5 つの画像を候補画 像として出力する. 表 11 に画像検索システムの仕様を示す. また, 図 7 に非常ににぎやか」,「非常に暗い」と入力し た場合の検索結果例を示す.

\section{2 システムの性能評価}

検索システムが出力した結果が, ユーザーの受ける感性や 印象に合致しているかを調べるために，アンケート方式の主 観評価実験を行った。評価基準は，以下の通りである。

・ 入力した印象とユーザーが感じ取る印象が一致しているか

- 出力された結果の順番が, ユーザーの求める画像の順番 に出力されているか

$$
\text { 適合率 }=\frac{1 \text { パターンの“○”の総数 }}{\text { 評価人数 }}
$$

表 12 に実験条件を示す。実験結果をもとに, 検索システ ムの出力結果と, ユーザーの受ける印象がどの程度一致して いるか適合率を求めてみた，適合率を式（15）で定義する。 


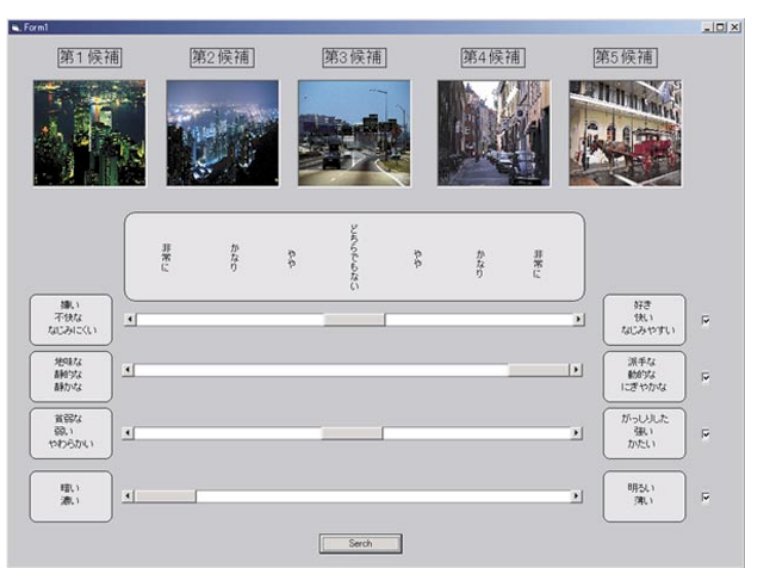

図 7 画像検索システムの検索結果例

\section{表 11 画像検索システムの仕様}

\begin{tabular}{c|l}
\hline 登録画像 & 景観画像 570 枚 \\
\hline & $\begin{array}{l}\text { 4 つの感性語群を検索キ一 } \\
\text { に7段階で入力 } \\
\text { ·単項目検索可能 } \\
\text { ·䦾意の組み合わせによる } \\
\text { 複数項目検索可能 }\end{array}$ \\
\hline 検索結果 & $\begin{array}{l}\text { 入力された条件に近いものを } \\
\text { 5つ提示 }\end{array}$ \\
\hline 動作環境 & Windows98以上が動く環境 \\
\hline 備考 & VB6.0のランタイムが必要 \\
\hline
\end{tabular}

表 12 性能評価の実験条件

\begin{tabular}{c|l}
\hline \hline 刺激材料 $\begin{array}{l}\text { 検索システムの検索結果 } \\
10 \text { パターン }\end{array}$ \\
\hline 使用尺度 & ○×で評価 \\
\hline 被験者 & 13 名 \\
\hline 手続き & 10 パターンの検索結果を順に提示 \\
\hline
\end{tabular}

評価実験の結果, 入力した印象のパターンが単純な場合 (「非常に好き」や「非常に暗い」など，4 尺度のうち 1 2 尺度を極端に設定した時）はユーザーが感じ取る印象と一致 しやすく, 複雑な場合 (4 尺度のうちの 3 尺度以上を「どち らでもない」から適度に変化させた時）は一致しにくい結果 になった。また， 10 パターン全体の適合率の平均值は 0.52 であった。

池添ら［7］と椋木ら［6］の研究においても, 感性検索 の結果を主観評価実験により検証しており, 検索結果に対し て $80 \%$ 前後の適合率が得られていると報告されている. 本 論文での主観評価実験を行った結果では, 第 1 候補の画像 では $90 \%$, 第 2 候補では 75\% 以上の適合率が得られている。 このことより, 本論文で提案する手法は, 従来研究の成果と 遜色ない結果が得られていると考えられる。

次に, 図 7 を例として検索結果の考察を行う. 図 8 は図 7 の検索結果例の候補ごとの適合率を示している. この検索結 果に扔ける平均適合率は 0.46 であるが，上位の候補がユー ザの要求と一致している，第 1,2 候補の適合率が高い要因 として, 夜景と昼景の違いがある. 第 1,2 候補の出力結果 は夜景であるため,「非常ににぎやか」、「非常に暗い」とい う印象を多くのユーザーが感じとっていた，一方, 第 3 候

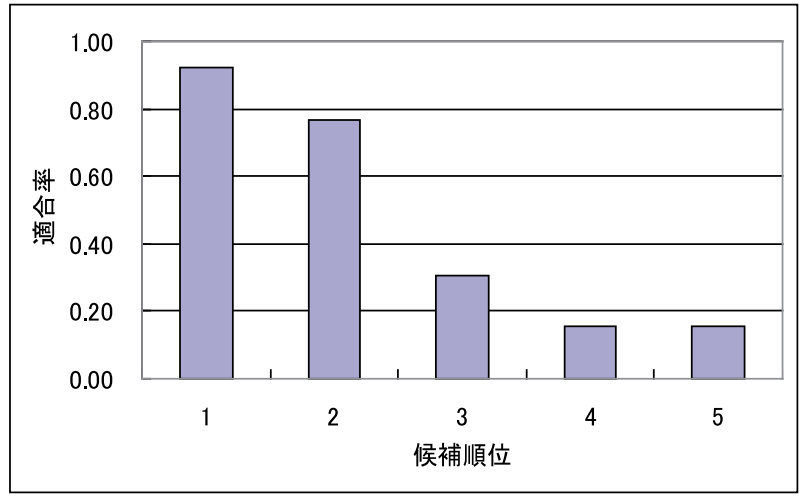

図 8 図 7 の実験結果

補以降は昼景であるため, 入力の印象と一致しなかったと考 えられる。このように，検索結果にはユーザが抄抄む満足 できる結果の画像が 2 枚程度存在していた.

なお, 今回の画像検索システムでは入力した感性情報と距 離の近いもの 5 つを提示しているが, 感性情報の空間の中 で 570 枚画像のばらつき具合によっては，このような提示 方法は必ずしも良いとは言えないと考えられ, 閾值処理と組 み合わせるなどの工夫により，提示枚数を適応的に可変させ ることにより，より利用者の感性に即した検索結果の提示が できると考えられる.

\section{9. おわりに}

本研究では, 画像から受け取る感性情報を得るための感性 モデリングについて検討した。 さらに, 得られた感性情報を 用いて画像を検索するシステムを試作した．実験結果から以 下のことが明らかになった。

- MPEG-7 のビジュアル記述子（SCD, EHD）の特徴量, 単色における色彩情報, Saliency Map を用いて距離尺 度を構成し，ポテンシャル補間による景観画像の感性情 報の推定を可能とした.

・ポテンシャル補間での類似度計算において，GAよる 重み付けを考慮することで, 推定の平均誤差は, 当初目 的としていた $95 \%$ 信頼区間程度となった。また，推定 の最大誤差は, どの因子においても目標を満たす結果は 得られなかった。特に, 因子 2 は平均誤差, 最大誤差 ともに大きく, 因子 2 を推定するためには, 今回用い た特徴量では不十分であり, 別の特徵量を考量する必要 があると考えられる。

・GAによる重み付けポテンシャル補間によって推定され た感性情報を，データのインデクシングに利用し，SD 法によって抽出された因子を入力キーとして画像を検索 する画像データベースを作成した。

今後の課題として, 画像データベースの実用化に向けた検 討が挙げられる。 


\section{参 考 文 献}

［1］栗田多喜夫, 加藤俊一, 福田郁美, 板倉あゆみ: 印象語に よる絵画データベース検索, 情報処理学会論文誌, Vol.33, No.11, pp.1373-1383 (1992).

［2］八村広三郎, 英保茂: 絵画に打ける感性情報の抽出, 情報処 理学会人文科学とコンピュータ研究会, Vol.24, pp.9-16(1996).

［3］田中昭二, 井上正之, 井上誠喜, 中津良平：誘目性に寄与 する物理的特微量を基にした画像注目領域の抽出, 映像情 報メディア学会誌, Vol52, No.6, pp.881-890 (1998).

４］木本晴夫：感性語による画像検索とその精度評価, 情報処 理学会論文誌, Vol.40, No.3, pp.886-897 (1996).

[5] 近藤邦雄, 高橋雅博, 松永政尚, 山崎秀樹: 画像データベー スのためのイメージカラー検索手法, 映像情報メディア学 会誌, Vol.54, No.11, pp.1615-1622 (2000).

［6］椋木雅之, 田中大典, 池田克夫：対義語対からなる特徵空 間を用いた感性語による画像検索システム, 情報処理学会 誌, Vol.42, No.7, pp.1914-1921 (2001).

７］＼cjkstart池添剛, 梶川嘉延, 野村康雄 : 音楽感性空間を用いた感性 語による音楽データベース検索システム, 情報処理学会論 文誌, Vol.42, No.12, pp.3201-3212 (2001).

[8］ 大橋俊道, 堀田裕弘, 村井忠邦, 中嶋芳雄: 景観画像を対 象とした感性語による画像検索法, 映像情報メディア学会 技術報告 HIR2000-141, pp.1-6 (2000).

[9] High Quality Digital Image for Professioal Vol.1-12, MUUSPROJECT

[10] Manjunath, B.S., Ohm, J., Vasudevan, V.V. and Yamada, A.:Color and Texture Descriptors, IEEETrans. CSVT, Vol.11, pp.703-715 (2001).

[11] 山田明雄：小特集マルチメディア内容記述の国際標猴 PEG-7, 2. 標準化された技術, 2-1. ビジュアル記述, 映像メ ディア学会誌, Vol.56, No.11, pp.1711-1714 (2002).

[12] Itti, L. and Koch, C. :A Saliency-Based Search Mechanism for Overt and Covert Shifts of Vi-sual Attention, Vision Research, Vol.40, No.10-12, pp.1489-1506 (2000).
[13] 堀田裕弘, 神田明典, 村井忠邦, 中島芳雄 : 単色刺激にお ける色彩感性值の推定と解析, 映像情報メディア学会誌,

Vol.52, No.4, pp.542-553 (1998).

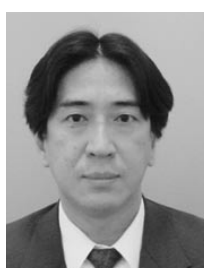

堀田 裕弘（正会員）

1986 年長岡技術科学大学大学院工学研究科 修士課程電気・電子システム工学専攻修了. 現在, 富山大学大学院理工学研究部 (工学) 教授. 工学博士. メディア品質評価, ITS, 感性情報処理などの研究に従事.

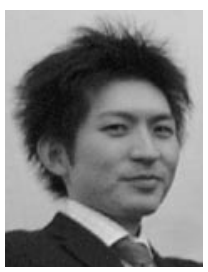

室岡 尚樹 (非会員)

2004 年 3 月富山大学大学院工学研究科博士 前期課程電気電子システム工学専攻修了. 在 学中, 感性情報処理などの研究に従事.

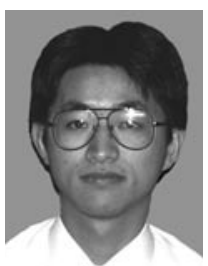

本田 和博 (非会員)

1997 年 3 月富山大学大学院工学研究科博士 前期課程電子情報工学専攻修了. 同年富山大 学工学部技術職員. 電磁界 - 音場の解析手法 に関する研究, 逆問題解析とその応用に関す る研究に従事.

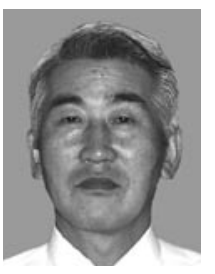

村井 忠邦 (非会員)

1967 年 3 月富山大学文理学部理学科卒業, 富山大学工学部助手, 講師, 助教授を経て 1991 年教授 (工学部). 現在, 富山大学大学 院理工学研究部 (工学) 教授. 工学博士. 電 磁界・音場の解析手法に関する研究, 逆問題 解析とその応用に関する研究, 落雷予測の基礎研究など数值シ ミュレーションに従事している. 